Review

\title{
Romanian Engineering "On the Wings of the Wind"
}

\author{
${ }^{1}$ Relly Victoria Petrescu, ${ }^{2}$ Raffaella Aversa, ${ }^{2}$ Antonio Apicella and ${ }^{1}$ Florian Ion Tiberiu Petrescu \\ ${ }^{1}$ ARoTMM-IFToMM, Bucharest Polytechnic University, Bucharest, (CE), Romania \\ ${ }^{2}$ Department of Architecture and Industrial Design, Advanced Material Lab, \\ Second University of Naples, 81031 Aversa (CE), Italy
}

Article history

Received: 09-01-2018

Revised: 12-01-2018

Accepted: 18-01-2018

Corresponding Author: Florian Ion Tiberiu Petrescu ARoTMM-IFToMM, Bucharest Polytechnic University, Bucharest, (CE), Romania E-mail: scipub02@gmail.com
Abstract: The presented study proposes a commemoration of the main artisans of the Romanian and world aviation, from its beginnings to the day. Very briefly are brought to the forefront, the main inventors of flying machines and equipment that have lived here in the Romanian territory and have contributed substantially to the development of any type of flight. We will talk about Traian Vuia, Aurel Vlaicu, Alexandru N. Ciurcu, Hermann Julius Oberth, Elie Carafoli, Anastase Dragomir, Radu Manicatide, Iosif Silimon, Elena Caragiani-Stoenescu, Petre Constantinescu, Dumitru Dorin Prunariu, Henri Marie Coanda, George (Gogu) Constantinescu. George (Gogu) Constantinescu (4.Oct.1881 - December 11, 1965) was a Romanian scientist and engineer, often considered to be one of the most important Romanian engineers. He was responsible for creating a new field of mechanics, called "sonicity," which describes the transmission of energy through vibrations in fluid or solid bodies. He applied the new theory to numerous inventions: sonic, sonic, sonic and others. Among other achievements, there is also a pulling device among the propeller blades regardless of its speed and the first automatic gearshift. He has actively participated in the construction of English aircraft, the Bristol type, while he lived in England. Henri Marie Coanda (June 7, 1886 - November 25, 1972) was an Academician and Romanian engineer, aviation pioneer, physicist, inventor, inventor of the reaction engine and discoverer of the effect that bears his name. Henri Coanda was born in Bucharest on June 7, 1886, being the second child of a large family (Henri had four brothers and two sisters, a total of seven children). His father was General Constantine Coanda, a former mathematics professor at the National School of Bridges and Highways in Bucharest and former Prime Minister of Romania for a short period of time in 1918. His mother, Aida Danet, was the daughter of French doctor Gustave Danet. Traian Vuia (August 17, 1872 - September 3, 1950) was a Romanian inventor and an aviation pioneer who designed, built and tested his own planes, which at the time were among the first heavier aircraft than the air. On March 18, 1906, he made his first selfpropelled flight (without catapults or other exterior means) with a heavier device than the air. In his first flight he managed to float about $12 \mathrm{~m}$ (40 feet) at Montesson in France on March 18, 1906. This was the first "certified" flight with the take-off and landing of the aircraft (unassisted from the outside), made with a monoplane aircraft powered by a wheelchair. Performing a mechanical flight with a heavier machine than the air was a fascination at the end of the past and the beginning of our age. Thousands of fools tried to accomplish it, while the "balloons," who at the end of the eighteenth century had managed to rise in the balloons of the balloons, were smiling with superiority, convinced that the future is theirs, those with more aerial vehicles light than air.

Keywords: Romanian Engineering, Social Sciences, Modern Transportation, Flight, World Aviation

C 2018 Relly Victoria Petrescu, Raffaella Aversa, Antonio Apicella and Florian Ion Tiberiu Petrescu. This open access article is distributed under a Creative Commons Attribution (CC-BY) 3.0 license. 


\section{Introduction}

It is said that "the Romanian is born poet". And so it is, but we could say rather that "the Romanian is born and an engineer", having deeply embedded himself, the vocation of the builder, the innovator, the inventor.

The great cathedrals, the beautiful monasteries built, or even the churches and churches (built or wooden) clearly show this vocation. After centuries, the "Voronet blue" still retains its vivid colors, even on the outer walls, beaten by rain, snow and wind. Suveica, the loom of war, the potter's wheel, the water and wind mills, the musical instruments, the wells or the fountains, the agricultural tools, the traditional Romanian houses with cerdac and porch, are only some proofs of the folk craftsmanship (engineering) over time.

Ever since the beginnings of civilization on today's territory of Romania, the inhabitants of these lands have been pioneers in creation and have thought of things that others have found much later.

Apolodor Bridge in Damascus is one of the ancient techniques of Romania. It was built between 102 and 105 AD by Christ of Emperor Trajan, Roman architect and constructor of Greek-Syrian origin, Apolodor (from Damascus) and "united" the Roman Empire with Dacia. The bridge was 1,135 meters long and 18 meters wide and was made of stone masonry with superstructure and oaken parapets. Among the last components were two small viaducts, also executed with stone masonry bolts and at each end of the bridge, above the grate, there was an impressive portal. One foot of this bridge is still preserved today in Drobeta Turnu-Severin (Aversa et al., 2017a-e; 2016a-o; Berto et al., 2016a-d; Mirsayar et al., 2017; Petrescu and Petrescu, 2016a-c; 2013a-d; 2012a-d; 2011a-b; Petrescu, 2016; 2012a-b; 2009; Petrescu and Calautit, 2016a-b; Petrescu et al., 2016a-c; Petrescu et al., 2017 a-1).

\section{Materials and Methods}

Traian Vuia (August 17, 1872 - September 3, 1950) was a Romanian inventor and an aviation pioneer who designed, built and tested his own planes, which at the time were among the first heavier aircraft than the air.

On March 18, 1906, he made his first self-propelled flight (without catapults or other exterior means) with a heavier device than the air.

In his first flight he managed to float about $12 \mathrm{~m}$ (40 feet) at Montesson in France on March 18, 1906 (Fig. 1). This was the first "certified" flight with the take-off and landing of the aircraft (unassisted from the outside), made with a monoplane aircraft powered by a wheelchair.

Performing a mechanical flight with a heavier machine than the air was a fascination at the end of the past and the beginning of our age.


Fig. 1: Traian Vuia's plane. This was the first certified flight of a heavier machine than the air that took off and landed alone without outside assistance. The flight took place on March 18, 1906, at Montesson, France

Thousands of fools tried to accomplish it, while the "balloons," who at the end of the eighteenth century had managed to rise in the balloons of the balloons, were smiling with superiority, convinced that the future is theirs, those with more aerial vehicles light than air.

Such flight attempts with heavier devices than the air had taken place and for each of them betting, forecasting, verdicts were given. It was a permanent dispute between old (oldest) aircraft with lighter-than-air vehicles and new supporters of airplane engineers (heavier than air airplanes capable of climbing and flying through the air, due to wings and of the engines available).

Finally, at the beginning of the 20th century (1903), two Americans, the Wright Brothers, managed to fly by plane. But their apparatus could not detach itself from the ground by the force of its engine, but was "launched", "propelled" by catapulting - that is, by an 
external impulse - and only then set it to heights. The first man who rose from the ground only by the force of his aircraft engine, making the first mechanical flight in the history of world technology, was in 1906 a Banat: Traian Vuia. But how many adverse circumstances had to conquer in order to realize his dream, how much perseverance he needed.

Traian Vuia was born in the commune of Bujor (nowadays named after him) in Caras-Severin County and he attended the high school in Lugoj, proving from his childhood his skill in various crafts.

In love with the technique and, above all, hoping to be an aviator, he enrolled in 1892 at the Polytechnic University of Budapest, School of Mechanics, where he received his diploma of engineer.

Attracting also to justice, he enrolled at the courses of the Faculty of Law in Budapest, who had a noncompulsory regime allowing him to work for himself (he could work in a legal office to earn his living).

After graduating from this faculty, he awarded his doctorate in law in May 1901, after which he returned to the country where he would practice as a lawyer in Lugoj.

But his great passion had not left him, moreover, he had managed to "dampen" her and others. He built the model of an "airplane-car" and, with the money he had hard-wired, but especially with those donated by several Romanians from Banat, depart for Paris, then "the capital of Europe and the headquarters of the world aviation".

Here he is addressing a memoir to the Academy of Sciences of France (February 1903), in which he presents his project, but the high scientific forum, dominated by the "balloons," rejects it, putting a verdict resolution that would sound ridiculous today, saying that trying to accomplish flying with a heavier device than the air "is a chimer" that "can only spring out of a sick mind."

Another would be discouraged. Vuia, however, trusts his idea and takes it further. "I do not work for my own personal glory, but I work for the glory of human genius," he often said.

In the same year, 1903, he patented his invention and proceeded to build the project, again helped with money from the Banat people. In 1905, after defeating numerous technical difficulties, the Vuia-I device (named by his friends "Lilacul" due to the shape of his wings) was ready: a lightweight monoplan with a tractive propeller and folding canvas wings, the landing train being made up of a pneumatic wheelchair.

On March 18, 1906, a historic date for world aviation, on the Montesson field near Paris, the "Liliacul" piloted by Traian Vuia takes its flight, taking off exclusively by the force of its engine without any external force "launching".

Later, Vuia built and experimented with new types of airplanes, also improved two helicopters (1918 and 1921), equipped with several propulsion and sustaining rotors, steering and horizontal stabilizers. He is also the inventor of an original steam generator (1925) of his own design, which has found a wide application in the construction of thermal power plants.

Traian Vuia, during the First World War, fought for the unification of Transylvania with the Land, even organizing the "National Committee of Romanians in Transylvania and Banat", editing a patriotic journal and manifestations. During the Second World War, though at an advanced age, was part of the resistance movement in France, being the president of the "Romanian National Front".

He returned to Romania in 1950, but died shortly after, crushed by a heavy disease, happy to revise his native landscapes and contented that he had achieved his life's purpose, the construction and testing of the first airplane heavier than the air, capable of fly.

Aurel Vlaicu (November 19, 1882, Binunte, near Orastie, Hunedoara County - September 13, 1913, Băneşti, near Câmpina) was a Romanian engineer, inventor and pioneer of the early and early Romanian aviation.

He finished the Reformed College of the Calvin High School in Orastie, which since 1919 was named "Aurel Vlaicu High School", taking his baccalaureate in Sibiu in 1902.

$\mathrm{He}$ continued his engineering studies at the University of Budapest and Ludwig-MaximiliansUniversität München in Germany, obtaining his engineer's degree in 1907.

He then worked as an engineer at Opel plants in Rüsselsheim.

In 1908 he returned to the Binnits where he built a sailboat with which he made a number of flights in 1909 .

In the fall of 1909 he moved to Bucharest and began building his first plane, Vlaicu I, at the Army's Arsenal. The plane flies without changes (unique for the beginnings of world aviation) in June 1910.

In 1911 he builds a second plane, Vlaicu II, which in 1912 won five memorable prizes (a first prize and four awards II) at the airship in Aspern, Austria. The competition gathered between 23 and 30 June 1912, 42 pilots from 7 countries, out of which 17 from AustriaHungary, 7 Germans, 12 from France, among them the famous Roland Garros, a Russian, a Belgian, a Persian and the Romanian Vlaicu. In the most famous Viennese newspaper, Neue Freie Presse, there were the following lines about Vlaicu's flights:

"Wonderful and courageous flights were executed by Romanian Aurel Vlaicu, on an original airplane, built by himself, with two propellers, among which the aviator. Whenever the car was spinning, it seemed to be overwhelmed, the world rewarded the Romanian with stormy ovations, acclaiming him with an unimaginable enthusiasm. "

On September 13, 1913, during an attempt to cross the Carpathian Mountains with his plane Vlaicu II, he collapsed near Câmpina (apparently because of a heart attack). 
In the following year, his friends Magnani and Silistea completed the construction of Vlaicu III and with the help of Petre Macavei, he made several short flights. Time authorities prohibit the continuation of attempts; in the autumn of 1916, during the German occupation, the plane was shipped to Berlin. It was last seen in 1940.

Alexandru N. Ciurcu (29 January 1854, Şercaia, Făgăraş County - January 22, 1922, Bucharest) was a Romanian inventor and journalist who experienced the principle of the reaction engine.

Alexandru Ciurcu was born on January 29, 1854, in Sercaia, Făgăraş county (in the current county of Brasov), his father being Neculai Ciurcu, a participant in the Revolution of 1848 in Transylvania. Alexandru Ciurcu followed high school in Brasov, taking the baccalaureate in 1872 .

He studied law at the University of Vienna between 1873 and 1876. At the same time, Alexandru Ciurcu also followed technical engineering courses.

He settled in Paris where he met a friend of his, Just Buisson (1843-1886). Besides the common profession, the two friends also shared a common passion for technique. Together with Just Buisson, he studied the propulsion of aircraft lighter than air (airships) as well as rocket engines.

At the 1881 Aviation Exhibition in Paris, an aero propelled by an electric motor was presented. Alexandru Ciurcu and Just Buisson propose instead of the electric motor to use a reaction engine and even obtain a first patent from France, which provides the possibility of a reactive flight.

To demonstrate the viability of their proposal, the two friends designed and built a propulsion engine based on combustion of gases in a small combustion chamber. The engine consisted of a 2-liter container with a $3 \mathrm{~mm}$ diameter hole. By combustion of gases the pressure inside the container amounts to 10-15 atmospheres.

Alexandru Ciurcu tried to get an interest in the experts of the French War Ministry on the new technology. On August 13, 1886, the two inventors experienced their engine for the first time in public by mounting it on a boat and sailing Sena against the current.

A group of experts from this ministry took part in this first engine experience. This experience is considered to be the first time a craft was propelled by a reaction engine.

Hermann Julius Oberth (June 25, 1894, Sibiu December 28, 1989, Nürnberg) was one of the founding fathers of rocket and astronautics.

Born in Sibiu (at that time Nagyszeben or Hermannstadt), Hermann Oberth was, besides Russian Konstantin Tiolkovski and American Robert Goddard, one of the three founding fathers of rocket science and astronautics. The three have never actively collaborated with the findings of their research being essentially identical, although research has taken place independently.
From the age of childhood (about 11 years old), Hermann was fascinated by this subject from Jules Verne's books, especially From Earth to Moon and Journey around the Moon, on the first confessing that reading it innumerable times, until he almost got to know her out.

Following the influence of these books and the personal conclusion that the ideas presented by Jules Verne were not entirely fanciful, Hermann built the first rocket model ever since the general school when he was only 14 years old.

Hermann Oberth realized that although the rocket fuel is consumed, thereby reducing the mass of the rocket, there continues to be a tank containing the spent fuel, which is no longer functionally useful. Hermann has thus independently developed the concept of combustion in fuel phases.

In 1912, Hermann Oberth became a medical student at the University of Munich, then participating as a military doctor during the First World War. Hermann later stated that the most important personal conclusion he drew from his experience was that he would never want to practice as a doctor. After the war, he returned to the same university, this time studying physics under the direction of some of the brightest minds of the time in the field.

In 1922, his doctoral thesis on missile science was rejected, being considered utopian. The work was, however, printed using private funds and produced controversy in the press.

Hermann later commented that he had deliberately refrained from writing another doctoral thesis with the stated aim of becoming a more valuable scientist than those who rejected it, even though they were not recognized by them. Oberth was a critic of the time education system, comparing it with a car with headlights back, lacking vision of the future.

In 1923, Hermann Oberth published the book Racheta in Interplanetary Space and in 1929, Ways to Travel in Space. In the years 1928-1929, Hermann worked as a consultant in Berlin for the first film in action-oriented history: Women on the Moon.

The film was produced by UFA-Film Co., directed by Fritz Lang and had a tremendous success in popularizing the new rocket science.

In the fall of 1929, Hermann Oberth launched his first liquid fuel rocket called Kegeldüse. In these experiments he was assisted by students from the Technical University of Berlin, including Wernher von Braun.

When building the world's first large rocket, called A4, but now known as V2, 95 of the inventions and recommendations of Hermann Oberth were used.

In 1938, the Oberth family moved from Sibiu. He first moved to Austria, where he worked at the Technical College in Vienna, then in Germany, where he worked at the Dresden Technical College, finally arriving at Peenemünde (under the false name Fritz Hann) where his student Wernher von Braun built already the V2 rocket. 
At the end of the war, Hermann Oberth was working at the WASAG complex, near Wittenberg, on solid-fuel rockets for air defense. After the war, he moved his family to Feucht, near Nuremberg.

In 1948, he worked as an independent consultant and writer in Switzerland.

In 1950, he completed in Italy the work he had begun at WASAG. In 1953, he returned to Feucht to help publish his Man in Space book describing his ideas about a space reflector, a space station, an electric space ship and cosmonaut suits.

Meanwhile, his former student, Wernher von Braun, had set up a space exploration institute in the United States of America in Huntsville, Alabama, where he joined Hermann Oberth.

Here Hermann Oberth was involved in a study called Space Technology Development over the next ten years. At the end of 1958, Hermann Oberth, again in Feucht, found time to put on paper and publish his thoughts about the technological possibilities of a monthly vehicle, a lunar catapult, a helicopter, a silent aircraft and others. In 1960, he worked for Convair as a technical consultant for the development of Atlas missiles in the United States.

Hermann Oberth withdrew in 1962, at the age of 68 . The 1977 oil crisis made it focus on alternative energy sources, leading to the concept of a wind farm plan. His main activities, after retiring, were related to philosophy, Hermann Oberth still writing some books related to this subject.

Hermann Oberth died on December 28, 1989, at the age of 95, at Feucht.

Hermann Oberth married 35-year-old Tilli Oberth (born Hummel), with whom he had four children, one of whom died in the World War II and a girl soon died in the August 1944, in an accident at work.

After his death, the Hersch Oberth Space Museum opened at Feucht, where his research and results are available to the public. Hermann Oberth, on the other hand, brings together scientists, researchers and astronauts from all over the world to continue their work.

Elie Carafoli (September 15, 1901 VeriaThessaloniki, Greece - 1983 Bucharest) Elie Carafoli, born in Veria, near Thessaloniki, was one of the most prestigious specialists in fluid mechanics and aerospace constructions.

He finished the Polytechnic School in Bucharest, where he obtained the electromechanical engineer's degree in 1924.

He continues his studies at the Sorbonne, becoming a graduate and doctor in physics and mathematics. During the three-and-a-half years of studies, he worked at the Saint-Cyr Aeronautical Institute and the Fluid Mechanics Department, publishing numerous theoretical and experimental works that are being printed in the French capital.
He returned to the country in 1928 and was appointed aerodynamic and mechanic assistant at the Polytechnic School of Bucharest and chief engineer of the design and testing studies department and then director of the IAR Brasov Cell Factory where he will remain until 1936.

Aerodynamics was a new discipline that emerged from the need to understand precisely the phenomena that took place around the plane in order to establish the most suitable forms for aircraft and to precisely determine the forces acting on their various organs, sizing and optimization.

At IAR Braşov he was noted for his intense activity, being a specialist in airplane construction and designing, together with Lucién Virmoux (representative of the Blériot Spad Factories), a low wing wing monoplanes, IAR-11 CV (in 1930), among the first of its kind in the world.

This hunting aircraft was equipped with a $500 \mathrm{hp}$ Hispano-Suiza $12 \mathrm{Mc}$ engine and was designed to overcome the speed record and climb ceiling $(5000 \mathrm{~m})$.

The main features of this airplane are 11.5 meters long, 6.98 meters long, wing area $18.2 \mathrm{~m} 2$, total weight 1.510 $\mathrm{kg}$, maximum speed $325 \mathrm{~km} / \mathrm{h}$, lifting height 10,000 meters; climbing time at 5000 meters $5 \mathrm{~min}$ and $15 \mathrm{~s}$.

Later, he designs and implements IAR-14 and IAR15 , also contributing to the design of the famous IAR80 (Fig. 2).

In 1931 he became a professor. His research into new, faster and more robust, rounded-edge wing shapes and profiles has been consecrated as Carafoli profiles.

In 1933 he became the definitive title teacher, he was already recognized for his original research on the infinite wing, the aerodynamic profile drawing methods, the visualization systems (called Toussaint-Carafoli), the permeable bearing surface theory, the lateral jet theory on the elongated wing wings small; develops finite-wing wing theory, wing-fuselage and wing-to-ground interaction, biplan theory and supersonic aerodynamics.

Carafoli solved a great deal of problems in fluid mechanics and general gas dynamics.

We also mention his contribution to the study of distorted wings, the determination of the distribution of the movement along the bearing wing and the fact that he gave the general formula of the downstream fault current.

He died in 1983 in Bucharest.

Anastase Dragomir (1896 - 1966) If at the end of the sec. XIX, beginning of the sec. XX, many aviation enthusiasts were preoccupied with the construction and piloting of planes, a young man named Anastase Dragomir focused his attention on the safety of flight equipment and especially of passengers on board. Anastase Dragomir was passionate, like many youngsters of that period, of aviation problems. 


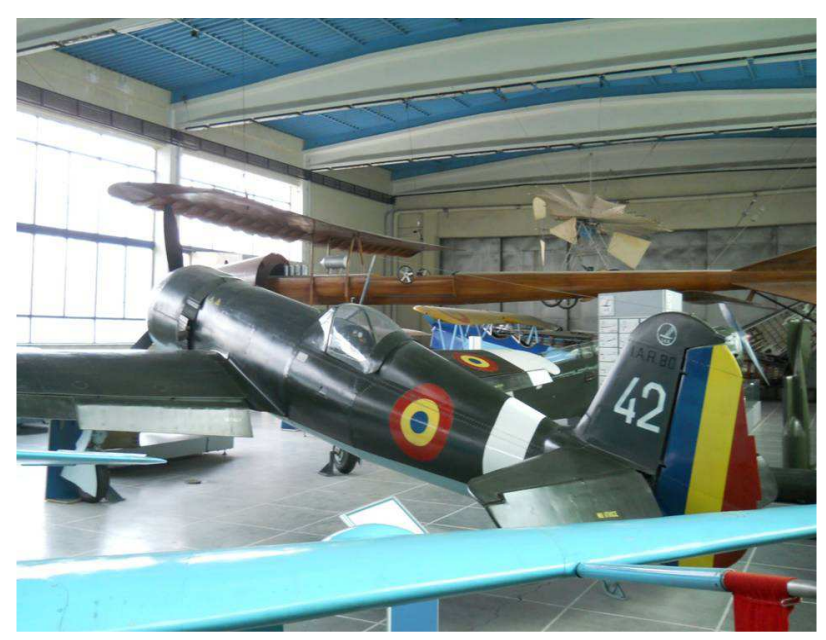

Fig. 2: It has an important contribution to the design of the famous IAR-80

He was a Romanian aviation inventor, best known for the invention of an early version of an ejectable chair, which was patented in Paris in 1930, which he benefited with another Romanian inventor, Tanase Dobrescu.

The invention consists of a so-called parachute cell, a removable and vertically ejectable seat (provided with two parachutes) of an aircraft or any vehicle designed to be used only in emergencies and which is an early version, but sufficiently sophisticated, of the current ejectable seats.

The model conceived by Dragomir and Dobrescu was successfully tested on 25 August 1929 at Paris-Orly airport, near Paris, France and subsequently in October 1929 at Baneasa Airport near Bucharest.

The following year, Dragomir and Dobrescu obtained the official patent of that "catapulting cockpit" at the French Invention Office under the number 678,566 of 2 April 1930 (but with the prioritization of the patent dated 3 November 1928, the date of filing the patent application - FRD678566 19281103), under the official name of the Nouveau système de montage des parachutes dans les appareils de locomotion aérienne (in Romanian, New parachute mounting system for airborne locomotives).

Radu Manicatide (April 17, 1912, Iasi - March 18, 2004, Bucharest) was a Romanian engineer and pilot engineer.

Among the engineers who contributed to the design and construction of their own design and construction aircraft, Radu Manicatide can not be omitted. He was born in Iasi on April 17, 1912 and he attended the Polytechnic School of Bucharest and the School of Aeronautics and Automobile Construction in Paris (where he was the head of the promotion) during 1931-1937.

As early as April 1926 he was preoccupied with aviation, winning with his own glider M-1, the first place in the airplane and sailplane contest.
In 1931 he made his pilot school, taking his patent.

In 1935, the RM-5 monoplane (with a maximum weight of $200 \mathrm{~kg}$ and maximum speed of $120 \mathrm{~km} / \mathrm{h}$ ) and RM-7 (with a maximum weight of $240 \mathrm{~kg}$ and a maximum speed of $135 \mathrm{~km} / \mathrm{h}$ ).

Since 1939, Manicatide, a structural engineer, worked at IAR Braşov, as head of the structure studies department, then head of the prototype and experimentation workshop where he participated in the IAR-27, IAR -37 and IAR-80) and under license (IAR79-Savoia Marchetti, Me-109-Messerschmitt).

Continuing his preoccupations, in 1942 he made the RM-9 monoplane (with a maximum weight of $350 \mathrm{~kg}$ and a maximum speed of $138 \mathrm{~km} / \mathrm{h}$ ) at IAR Braşov.

In 1944, Radu Manicatide made the plane-mounted biplane plane, the RM-11 (with a maximum weight of $530 \mathrm{~kg}$ and a maximum speed of $175 \mathrm{~km} / \mathrm{h}$ ) and in 1949 also built the Brasov airplane Ibr-811 school bibloc (with a maximum weight of $650 \mathrm{~kg}$ and a maximum speed of $150 \mathrm{~km} / \mathrm{h})$.

Since 1950, the IAR-813 (with a maximum weight of $750 \mathrm{~kg}$ and a maximum speed of $192 \mathrm{~km} / \mathrm{h}$ ) has been built under the leadership of the URMV 3 Factory Repair Facility, with which it has obtained homologated records International Aeronautical Federation.

In 1953, he designed and built the IAR-814 bumper jet (with a maximum weight of $2,030 \mathrm{~kg}$ and a maximum speed of $272 \mathrm{~km} / \mathrm{h}$ ), which also achieved a world-class closed circuit speed certificate, certified by FAI.

Since 1955, also at URMV 3, the IAR-817 aircraft (maximum weight $1.150 \mathrm{~kg}$ and maximum speed 175 $\mathrm{km} / \mathrm{h}$ ) were built.

Radu Manicatide moved to Bucharest, at the Aircraft Company, in series IAR-818, which entered the agricultural aviation aviation facility.

In 1956 he created the MR-2 bomber, derived from IAR-814 (with a maximum weight of $2,080 \mathrm{~kg}$ and a maximum speed of $275 \mathrm{~km} / \mathrm{h}$ ).

After 1967, Radu Manicatide, in collaboration with the Institute of Fluid Mechanics and Aerospace Research, designed the IAR-822, IAR-823, IAR-826 and IAR-827 planes at ICA Ghimbav.

Iosif Silimon (July 22, 1918, February 19, 1981) was an outstanding designer and builder in the field of gliders and motoplaners.

He was born on 22 July 1918 and attended the Polytechnic School in Bucharest, which he graduated as an electromechanical engineer in the aeronautical specialty in 1941.

Starting with the same year, Silimon joined the IAR Braşov at the study offices and then became the head of the light aircraft production workshop.

In 1944, he was appointed head of the assembly section and after 1945, with the transformation of IAR into a tractor factory, he participated in the first Romanian tractor, IAR-22. 
Since 1949 , began to build IS-type sailplanes, designing and building over 30 types of sailplanes and motorbikes.

Silimon was also a planetary pilot, taking the patent in 1944 at Sânpetru Aeroclub and in 1947 the pilot of airplanes.

In 1956, he obtained the silver C badge of the FAI for his performance in piloting the glider.

In 1949, he made his first sailplane, Sânpetru, IS-2, continuing after 1950 at URMV 3 with IS-3.

$\mathrm{He}$ was the main artisan of the restoration of the industrial tradition in the branch, in Braşov and of the establishment in November 1968 of the Aeronautical Construction Company of Ghimbav, where he was chief engineer and then, since 1980, technical director.

In addition to the design of gliders, he designed and supervised the construction of IS-23 and IS-24 aircraft.

He supported the Franco-Romanian collaboration in helicopter construction, coordinating the development of the Alouette and Puma helicopters under the AEROSPACE license.

In 1976, he built the IS-28 M2 billiard truck, which flew the distance between Braşov-Tocumwal (Australia) on a $18,000-\mathrm{km}$ route, which is a performance.

In 1977, he designed and built the prototype of the IS-28 M1 tandem billiard prototype and the prototype of the IS-32 performance billiard, with a 20-meter range.

With its IS-28 B2 billiards, the world record of 829 kilometers in Pennsylvania was obtained in April 1979 by two US pilots.

One of the concerns of Silimon engineer was also the development of air-cushion vehicles for utility purposes.

He dies on 8 February 1981, only 63 years old.

Elena Caragiani-Stoenescu (May 13, 1887 - March 29, 1929)

He was born in Tecuci on 13 May 1887 as the first daughter of the illustrious doctor Alexandru Caragiani and Zeniei Caragiani - born Radovici. The Caragiani family immigrated to Wallachia from Macedonia, from Avdela, Pind. Her father was the brother of the distinguished professor of Hellenic literature, academician, member of Junimei - Ioanne Caragiani.

Alexandru Caragiani has been distinguished since the Independence War, reaching the gates of Vidin with the first sanitaries, as a medical student. The doctor's degree was obtained in 1878 in Vienna.

Elena Caragiani was already licensed in Law when the first wings appeared in the West as they stood in the tracks without traces of the air.

He was interested in flying to some competent people, such as pilot Lieutenant Andrei Popovici (later general), who, by marrying her sister Florica, became a brother-in-law.

Then the first flight was made in 1912, with the former equestrian partner, the captain Mircea Zorileanu - pilot patent holder no. 3, freed from France in 1911. From now on, the mirage of heights has captured it definitively.
He enrolled at George Valentin Bibescu's Airline Pilot School, having as instructor Constantin Fotescu.

Her presence among the aviators has caused great indignation. Elena did not get discouraged and continued with the lessons with Captain Nicu Capsa, holder of the patent no. 4, liberated by a Parisian school and Mircea Zorileanu, who, in World War I, would have been hung up by his weapons deeds.

Once the school was finished, she would receive the civilian pilot's patent. All requests to this effect submitted to Minister Spiru Haret and General Crăiniceanu were rejected.

Indignant of this injustice, she was forced to leave the country in France, where she enrolled at the Mourmelon le Grand Aviation Civil School in Champ de Chalon, led by Roger Sommer, where she was ready for the theoretical and flight exam on who took them well. The International Aeronautical Federation has issued the International Pilot Pilot Pile with no. 1591 of 22.I.1914.

In 1914, there were around ten women around the world, including Elena Caragiani, Romanian.

Romania entering the Balkan war has taken steps to be admitted as a fleet, even as an air observer. And now it was rejected.

Sister of advice, went to France where he hired as a reporter at a big daily newspaper, where he used the plane for long journeys. This gave the idea of the press consortium leaders to engage in the role of war correspondent. Here he made numerous flights, writing "airplane reports", being the first of its kind in the world press.

This service has made it travel much to the other continents. She participated in actions totally unusual for a woman: she hunted the jungle (the press reported that she had killed a dangerous elephant alone), shot tigers, hunted whales and handled the harpoon very well.

In America, the presence of the Romanian aviator has not gone unnoticed by the daily. The articles that appeared even briefly present Elena Caragiani's personality. Thus, in the German newspaper Staats Zeitung, he is among the passengers of the white line ship "Olympia" of White Star alongside distinguished personalities such as: Paul Reboux - French writer, count and Countess Dunmore, exsenator of Illinois, Wiligm Lorimer and known sister Katherine and Charlotte Poilon.

At the descent, he told reporters who assaulted her that he wanted to get along with American aviators to organize air raids across the Atlantic, he wanted to get American pilots to fly over the ocean. For any event he brought his own plane, a Blériot, a monoplane he would train in the city of Golden City, Long Island, as soon as he assembled it.

The first big world conflagration in 1916 had a deep echo in her soul. The country has been in a heavy mood 
and has returned to duty, believing that it has to help defend the native country with as little as possible. He renewed his request for admission to the body of the fighters and to fight on the front. It did not succeed this time, perhaps because the total number of aircraft with which Romania entered the war was only 26.

Seeing herself refused again, she asked that she at least get to carry sanitary napkins and medications on the front and from the first line hospital hospitals, to evacuate serious injuries to the inner hospitals. With this proposal, Elena Caragiani foresaw the establishment of sanitary aviation, a desideratum that has been achieved in our country for a quarter of a century.

He made a raid - in the country being - from Craiova to Tecuci, a very important thing for those years.

After the war he married his lawyer Virgil Stoenescu with whom he settled in Paris.

From here he was sent to Mexico by a large French daily as a reporter for airline events.

The too much effort they made has made them feel sick of frosty (TBC), which it slowly and ungluvelously crushed. Unfortunately, for everything he had known, he had retired to his native country as a resting place for the fallen body.

He died alive at the age of 42 on March 29, 1929 and was buried at Bellu Cemetery (figure 45 bis, 13th place), a place shrouded in shadow and silence, as he wished.

Petre Constantinescu (November 08, 1914 - January 29, 1992)

He was born on 8 November 1914 in the city of Buzau.

After graduating from high school in Buzau, he attended the School of Artillery Officers in Timisoara, which he graduated in 1935 and then the Special School of Artillery in 1936 in Bucharest.

In January 1939 a total of 30-40 officers (subdeputies and lieutenants of infantry, artillery, cavalry and navy) from all over the country met at the Aviation Training Center at Pipera Airport in Bucharest to attend a training course air observers in land and marine weapons. These, detached in aviation warfare, were to ensure the co-operation of aviation intelligence and reconnaissance with other weapons. Among them was the artillery sub-deputy Petre B. Constantinescu. All were posted on a personal request.

Patented Air Observatory on August 1, 1939, Second Lieutenant Petre B. Constantinescu makes a request to the Aviation Training Center for a definitive aviation transfer, followed by one more school: the Complementary Technical Course with a duration of one year.

At the beginning of November 1939, all those who had made the same request met at the Aviation Officers School in Cotroceni where a special class of new avionics from other weapons was established.

On October 31, 1940, at the Otopeni airfield, with the minutes Nr. 108, the Board of Trustees composed of aviator Scarlat Rădulescu commander of the Schools and Aeronautical Centers as Chairman and members: Commander Captain Gh. Davidescu, Commander Caloianu Aviation - CFA Delegate, Aviator Captain Poparda Vasile - Pilot Chief and Aviator Captain Lăzărescu Florea - , following a test run by each pilot, granted them the "pilot of war" patent. Thus, the Second Lieutenant Petre B. Constantinescu acquires the pilot of warfare patent and is then definitively confirmed in aviation.

Several of the recent war pilots, including Petre B. Constantinescu, are stopped at the Aviation Officers School as a school inspector and commander of the students' section.

In July 1941, the Aviation Officers School split the fresh graduate promotion into two groups. A first group those who were to become hunting pilots - was sent to the Ghimbav Pilot Training Center. Petre B. Constantinescu was the commander of this group with administrative and discipline issues. The second group with those destined to become bombing pilots - was sent to Turnu-Severin. Commander of the group of future bombers was named lieutenant Alexandru Şerbănescu.

Once in Ghimbav, Lieutenant Constantinescu B. Petre sends a report to Bucharest to the school master asking for his approval to do the training school to become a hunting pilot. The request was also approved on 7 October 1941 - with the minutes $\mathrm{Nr}$. 8, signed by aviator commander Budac Coriolan, commander of the Training Center and Captains Suciu and Deac - is patented hunter on PZL 22B.

Second lieutenants, whose administrative commander was, continued training and later they were also patented direct hunting war pilots.

In January 1942, at his insistent request to be moved to a combat unit, Petre B. Constantinescu was transferred to Fleet 3 Hunting Galați where Commander Marasescu Anton (Mache) was then commander. This is part of the 50th Hunt Escadrille commanded by Captain Enea Constantin and based on the White Fortress airfield.

Between June 27, 1942 - July 31, 1942, he performed 31 war missions, protecting the Black Sea coastal convoys in the Burnas-Odessa area.

It is advanced to the rank of captain aviator.

From May 1, 1943 to October 8, 1943, Captain Aviator Petre B. Constantinescu is the commander of the 45 Fleet Hunt Escadrille 3 Hunting Galați, detached at Târgşor with the mission of defending the oil area against possible attacks by Anglo-American aircraft. The squadron runs patrol missions daily in the area. The planes he flew - IAR 80.

On August 1, 1943, the Squadron 45 Hunt participated in the Campina area against the 175 Liberator quadrilateral bombers, firing five of those planes.

After this air squadron battle passed from Fleet 3 Hunting Galatii in the composition of Hunting Targusor Fleet 2, having the name of Squadron 59 Hunting and being commanded by captain aviator Petre B. Constantinescu. Old, tired and insufficient aircraft (only five left) were replaced by 15 new IAR $81 \mathrm{C}$ planes. 
On October 9, 1943, the squadron changed the aerodrome, installing itself on the Popeşti-Leordeni airfield, Bucharest. At the beginning of November 1943 arrived at Popeşti-Leordeni and the Squadrons: 61 Hunting commissioned by Lieutenant Aviator Dumitrescu Mircea and 62 Hunting commissioned by Lieutenant Aviator Posteucă George. The three squadrons consisted of Group 6 Hunting commissioned by captain aviator Vizanti Dan Valentin. Squadron 59 Hunting had been the isolated squad ever.

Thus formed, the 6th Hunting Group acted between October 1943 and August 23, 1944, on all day-battles against American bombing and hunting aviation.

Captain Aviator Petre B. Constantinescu flew at the head of Squadron 59 Hunting in all combat missions, less two.

\section{April 5, 1944}

Captain Petre B. Constantinescu sailed a BoeingFortress; area - above Ploiesti; flight altitude $7500 \mathrm{~m}$. The captain was at the head of the Squadron Hunting, flying that day IAR 81 no. 313.

It was a lucky day: all the planes returned to the base, many carrying the holes left by the projectiles on the fuselage and on the wings.

April 24, 1944

Days in which Americans bombed both Ploiesti and Bucharest. Group 6 Hunting is directed by "Tiger" to act in Bucharest. Height $7500 \mathrm{~m}$.

Squadron 59, in plan-to-plan formation, is attacking the band Liberators from the top right. Constantinescu B. Petre caps the plane to the right of the band's head. Shoots from $200 \mathrm{~m}$ to nearly $100 \mathrm{~m}$ when it turns around turning to the right. He clearly shows how he jumps from the right wing; also, how a side door opens up on the fuselage and, one by one, the crewmen jump with the parachutes.

All squad pilots loosened their machine guns and cannons over the flying fortresses to the right of the formation, watching the jerks of the tractors they sent penetrate into the fuselages and wings of the huge planes. Then the squadron repeats the attack on the cells, pulling successively into the enemy formation.

Arrive well on the aerodrome, feel the joy of life and the lucky end of the battle. He controls his planes, counts the holes on them and rejoices that the American bullets have not touched them.

\section{May 5, 1944}

A strong formation of Boeing-Fortress attacks Ploieşti. Group 6 Hunt came forward. On this day Squadron 59 is the head of the group. Flight height $7000 \mathrm{~m}$.

At the front (bottom-up) attack IAR 81C no. 317 piloted by captain aviator Petre B. Constantinescu is damaged by the enemy shooting while the captain executes the firing with all the weapons of flight. The engine stopped and the captain was taken out of the battle. He managed to land the plane on his stomach on a pile of about $2 \mathrm{~km}$ from Cornățelu commune, Dâmbovița County. The plane was recovered and sent by train to IAR Braşov for repairs.

Based on the proposal made by Group 6 Hunting after the battles that took place until May 5, 1944, aviator captain Petre B. Constantinescu is decorated with the Aircraft Virtue with the gold cross with the first beret.

May 31, 1944

In the area of Ploiesti, he fights with the Liberator air force that bombs the Romanian-American Refinery. Captain Constantinescu B. Petre takes down a Liberator plane. Flight height $7500 \mathrm{~m}$.

June 10, 1944

A formation of lightning-type American jet fighters is attacking the Popeşti-Leordeni airfield after 11 o'clock. Alert in time, Group 6 was in the air, above the aerodrome at $3000 \mathrm{~m}$. That day Squadron 59 took off last.

The battle was gathered in close proximity to the village of Frumuşani, south of Bucharest. A group of Lightning was attacked by Squadrons 61 and 62, headed by the Commander of the 6th Hunt, Lieutenant Commander Aviator Vizanti Dan and Second Squadron 59 headed by Aviator Captain Petre B. Constantinescu. The fight lasted about $15 \mathrm{~min}$ and a total of 25 enemy planes were shot down. A Lightning was shot down by Captain Aviator Petre B. Constantinescu who piloted IAR $81 \mathrm{C}$ no. 313 . The battle height was between 50 $150 \mathrm{~m}$.

At the regrouping of the 59th Squadron in India to go on landing, the Bucharesters who had come out of town on the Oltenita highway, near the Bucharest ring line and had the unique opportunity to be spectators of the close combat, made the planes joyful, throwing up hats and other objects.

From the 59th Squadron, all the planes returned from the battle with their unharmed pilots.

From Squadron 61 fell Giurgiu adjutant in battle.

From the Squadron 62, there were no airplanes of Lieutenant Aviator Limburg Nicholas and aviator Tari Victor. They collided in the air in the tangle of the struggle. Both pilots died.

From the 59th Squadron, the Nanculescu Mechanical Officer died who, after take-off of the combat hunting planes, climbed into one of the non-vista flying schools that dispersed the planes and staff. But the attacking Lightning surprised them when they were still running on the ground to the take-off point; some have burned them and made many victims.

June 23, 1944

Alarmed, Group 6 Hunt was in the air at $6500 \mathrm{~m}$ high, halfway between Bucharest and Ploiesti. On that day they were together with Captain Aviator Petre B. Constantinescu, on the flight of the Squadron, seven more teammates. They are attacked by a formation of Mustangs that plunged above the squadron and from the sun. The far right of the band, aviary adjutant Dimache 
Constantin, is hit by a blast of Mustangs and a fired plane. He jumped on the parachute, but the shock caused by the automatic parachute opening pulled the safety belts from his shoulders. He grasped the legs between his legs, but with burns on both hands, he could not keep the parachute until it landed. He fell from the parachute on the ground with his head down and died.

Admiral Dimache Constantin had a special artistic talent. At the end of the war, he was to become a member of Constantin Tanase's band Cărăbuş Theater, with which he had already signed a pre-contract. He was the one who sang the song "Costic, Costic, make the lamp smaller ...". Unfortunately, at the end of all the hostilities, there was neither him, nor even the great Constantine Tanase.

The other planes, hunting under the assailants, woke up isolated from the group and engaged in battle with the Mustangs. Constantine B. Petre, aviator captain, remained alone in battle with three Mustangs who chose to attack him in the Indian line, trying to break him down using their higher speed and their stronger armament. Captain Petre B. Constantinescu was forced to speed by hijacking the plane and when it was considered appropriate - when the Mustang planes were firing the machine guns, they would turn in short, taking advantage of the superior maneuverability of the Romanian IAR $80 / 81 \mathrm{C}$. So he managed to avoid the first attack, but he found that, on leaving the brutal turn, he could trigger the attack on the last Mustang of the American plane. The battle continued and the attackers returned to the last plane in the Indian hunting row. The other two US planes decided to give up the fight and withdrew. It was a desperate action of Captain Petre B. Constantinescu but who gave courage and confidence to the Romanian aviators of the Ploiesti and Bucharest Defense Group.

In September 1944, captain Petre B. Constantinescu was transferred to the Aviation Training Center at Buzau and Cristian - Braşov on request and on 22 February 1946 he was put in reserve, according to the data published in newspapers under the heading "Active Officers Passed in the reserve "in the chapter" Aviation "where his name then appeared with the aviator Chiaburu Rodion.

On March 22, 1947, he was turned back to the rank of commander and after 1990 he was promoted to Lieutenant Colonel of Aviation.

In civilian life he traveled a beautiful constructor's career progressively advancing from the master builder to Sovromconstructii 4 Trust 16 Moineşti to the subengineer in construction grade 6, head of the Exploitation Mapping Design Workshop within the Department of Systematization and Design in Construction (DSAPC) Iaşi.

Working in Moinesti he conceives a detachable octagonal barrage designed for workers working on isolated sites, patented as an invention and used in the construction stage at several locations in Romania.
For his professional work in construction he is awarded the Jubilee Medal of the Trade Union Committee for Special Merits in the Socialist Contest for five consecutive years and on 22 April 1968 the Labor Medal.

He quit us on January 29, 1992, in Iasi.

On his cross is written:

We have learned from our parents to live nicely, even if not easy and always have the pleasure of our work.

Dumitru Dorin Prunariu (born September 27, 1952, Brasov) is the first Romanian cosmonaut.

On May 14, 1981, he became the first and for the time being the only Romanian ever to fly into outer space. He participated in Soiuz 40 mission within the space program "Intercosmos" and spent space in 7 days, $20 \mathrm{~h}$ and $42 \mathrm{~min}$.

$\mathrm{He}$ is an aeronautical engineer. He was an engineer officer at the Military Aviation Command, Head of Romanian Civil Aviation, President of the Romanian Space Agency, Ambassador of Romania to the Russian Federation, President of the Council of NonMilitarization of the Cosmic Space of the UN. Currently he has the rank of major (2-star) in reserve.

Born in the city of Brasov on September 27, 1952, Dumitru Prunariu graduated from the Maternity-Physics High School nr.1 in his hometown in 1971. His father was an engineer and the mother of a teacher at a general school. Prunariu's passion for flight has been manifested since childhood, as stated in an interview:

"I wanted to fly by little child. I closed my eyes and I felt floating over the mountains, valleys, discovering new worlds. I always fascinated the blue abyss, the infinite heights.

Finally, I got to fly into the Cosmos. Fulfilled dreams are like a circle of light on the trunk of life, a beneficial irradiation. In the cosmos, your close universe is no longer represented by the house, the street, the neighbors, but the natal planet itself. The Earth, besides the physical dimension you can appreciate directly, at its true value and greatness, has a strong moral dimension. From a cosmic flight, you are turning back on yourself, more mature, closer to people and nature, with a more global vision of earth phenomena and activities. Though you're not alone in the flying machine, loneliness, up there, is pretty strong. You suddenly feel broken by your natural environment in which you were born and developed."

Little Prunariu began his way to the stars from the airplane circle at the Pioneers House in Brasov, where he built models of sailplanes and airplanes, dreaming of becoming a builder of aircraft. He was 17 when he won the Republican Prize at the Minitehnicus Technical Creative Contest. On this occasion he received Minitehnicus nr. 103. 11 years later he would become the 103rd Earthman who came to the Cosmos.

He graduated from the Faculty of Aerospace Engineering from "Politehnica" University of Bucharest 
in 1976 with the specialization of aeronautical engineering. After completing university studies, he worked as a trainee engineer at the Aeronautical Construction Company (IAR) in Ghimbav (Brasov County) between 1976-1977. Then, in the book "Five Minutes After the Cosmos," written together with the journalist Alexandru Stark, Prunariu would have said that if he had not been co-opted into the detachment of cosmonauts, he would have built with the wife his helicopters and planes so coveted in childhood.

In 1974 he married Crina Rodica Prunariu, with whom he was a colleague of the faculty, currently a diplomat in the Ministry of Foreign Affairs, being since 2007 the ambassador of Romania to Armenia. In 1975, their first son was born, Radu-Catalin and in 1977 his second son, Ovidiu-Daniel.

In May 1977, selections were launched for the Cosmos Intercosmos, initiated by the USSR and addressed to the Allied Socialist countries. Initially, more than 150 candidates were volunteered for the detachment of the cosmonauts, most of them superiors and engineers. $<<$ The Intercosmos Program was a welldefined cosmic program that had very clear provisions and a well-defined evolution: from experiments that were carried out automatically on board various highaltitude missiles or Soviet space ships to complex experiments made by cosmonauts

During the military training at the Aviation Reserve Officers School in Bacău in May 1977, then the commander of the military unit, Lieutenant Colonel Ioan Sandulescu Stahie (who later became General Aviation Commander and fulfilled as Commander of the Aviation and Anti-Territorial Defense Department until 1997), entered the course and advised TR military engineers that selections for the Intercosmos program were made. 17 of them accepted. After conducting medical tests in Bucharest, all 17 were rejected. The reason for Prunariu's rejection was the fact that in the stress tests, against the background of a momentary flu, there were disturbances of the heart's parameters. Two months after the rejection, the files of five candidates, including Prunariu, were resumed and this time managed to successfully pass all the evidence. Of all the selection groups, seven candidates remained in that phase, two gave up for personal reasons and two were removed after an initial training and final testing phase in the country.

Dumitru Prunariu finalizes, in September 1977, the courses of the Aviation Reserve Officers School in Bacau, with the rank of second lieutenant in reserve.

In the autumn of 1977, the cosmonaut candidates were sent from their jobs to the Aviation Military Unit in Bacau, being included in a multidisciplinary training program. The training included a series of theoretical training courses at the Military Academy in Bucharest, several dozen flight hours on MIG 15 planes conducted in Bacau and physical education and Russian language courses at Poiana Braşov. The officer in charge of physical training had been ordered in two months to remove the athletes from high performance cosmonaut candidates. Against the background of exaggeration in demands for physical exercise without adequate recovery periods, Prunariu's characterization was written: "some lack of will in physical training." On January 1, 1978, however, three candidates were selected as members of the cosmonaut training group within the Intercosmos Romanian-Soviet Space Mission. The three candidates were Eng. Dumitru-Dorin Prunariu, Eng. Cristian Guran and Captain Eng. Mitică Dediu. Before Dediu's cosmic flight was officially changed his name from Mitica to Dumitru and with regard to Dumitru-Dorin Prunariu it was decided that in the press he would only appear with the surname Dumitru.

These three went to Moscow to undergo a final assessment by Russian specialists from the Institute of Biomedical Research in the field of aviation and cosmonauts. Dumitru Dediu was 10 years older than Prunariu and 9 years old than Guran and he was considered a favorite by the military rules. After the tests in Moscow, Cristian Guran (very well professionally trained) was eliminated from the team of potential Romanian cosmonauts due to problems of the vestibular apparatus.

Eventually, Prunariu and Dediu were elected to carry out the entire training program to become cosmonauts. "My physical condition, that is, sport, I wish. It has only improved to the Russians. Medical, we passed all the tests, "says Dumitru Prunariu. Dumitru Dediu, though he did not have the best performances in the scientific, physical and medical excellence.

For three years, between March 1978 and May 1981, Prunariu and Dediu followed a specialized training as cosmonaut candidates at the "Iuri Gagarin" Cosmonaut Training Center in Zviozdni Gorodok - "Stelar City" (near the Moscow).

The second Intercosmos group, which began training in March 1978 in "Star City", consisted of two candidates from five countries: Bulgaria, Hungary, Cuba, Mongolia and Romania. At that time, the representatives of the first Intercosmos group, made up of Czechoslovakia, Poland and Democratic Germany, already flew into the cosmos. After a year, on political grounds, the Russians also brought in Vietnamese candidates included in the second Intercosmos group. All foreign cosmopolitan candidates lived in "Stelar City" together with their family, a condition imposed by the Russian side, which was a beneficial thing for all, the family having the opportunity to morally support their candidate, to learn the language and to integrate with the environment there.

On May 12, 1981 Dumitru Prunariu was officially confirmed as the first nominee in the Romanian-Soviet space flight, along with the Soviet cosmonaut colonel 
Leonid Popov-crew commander. He was an experienced cosmonaut and had made a 186-day flight on board the cosmic station "Saliut-6." The Romanian cosmonaut Dumitru Dediu and the Soviet cosmologist Iuri Romanenko were named as reserve crew members. received the news with resignation, especially since it came on his birthday: "It was not easy-he admits - but that's fate, we knew from the beginning that only one of us would fly." Of all the candidates in the Intercosmos program, Prunariu was the only cosmonaut who achieved the maximum qualifying examinations and final tests, in contradiction with Dediu who had to repeat some exams to qualify at least for the reserve crew.

"For me, the purpose of the whole preparation was cosmic flight, as it was normal. Throughout the training period I never thought of what would happen afterwards, "says Dumitru Prunariu.

After the major accident that interrupted the flight of the first Bulgarian cosmonaut in 1979, the entire Intercosmos program was offset by one year. Faced with this postponement, Soiuz-40 missile decommissioning was also postponed by a few days to the scheduled date due to faults discovered before lifting on the launch ramp.

Nearly three weeks before launch, the two main crews, both reserve and backup, were brought from the Stelar City by Moscow to Kazakhstan's Baikonur cosmodrome, where they continued training for launch.

Towards the evening of May 14, 1981, a special bus brought the two senior flight crewmanships to Platform 17 at the Baikonur cosmodrome: Soviet Colonel Leonid Popov, who a year ago achieved the long-term record in alien space for 185 days and Lieutenant Major Engineer Dumitru Prunariu. Two hours before the start, the crew occupied the launch position in the spacecraft's shell at the top of the carrier rocket, carrying out a series of tests of the ship's equipment and systems until launch. At 20 16 '38 (Bucharest time), the Baikonur cosmodrome was launched with the Soiuz-40 cosmic spacecraft (weighing 300 tons in total), carrying on board the Soviet-made Soviet crew consisting of the major pilot lieutenant Eng. Dumitru Prunariu and the colonel Leonid Ivanovici Popov. After $8 \mathrm{~min}$ and $50 \mathrm{sec}$, the spacecraft was breaking off from the last stage of the carrier rocket, already $220 \mathrm{~km}$ altitude, approx. 3000 $\mathrm{km}$ from the launch point and moving around the Earth at a speed of $28,000 \mathrm{~km} / \mathrm{h}$ in an orbit inclined to the equator by $51,6^{\circ}$. Prunariu became the first Romanian in history to fly in space. According to Intercosmos flight planning, the flight would take almost 8 days, from May 14 to May 22, 1981.

The take off went smoothly. After enrolling in circumnavigation orbit, verifying the technical parameters of the ship in real flight conditions and performing the first orbital orbiting maneuver, which lasted until 4 am the next day, the two cosmonauts were allowed to strip off the cosmic diver's costumes, go into the orbital module and rest. They woke up the next day at 12 o'clock and after eating, they performed the second maneuver of lifting and correcting the spacecraft's orbit to begin coupling maneuvers with the Saliut-6 orbital station. At the coupling, Soiuz-40 had a relative speed to the station of $0.3 \mathrm{~m} / \mathrm{s}$. "We hear the neighbors, Kovalionok and Savinish, who are in the cosmos since March."

On May 15, Soiuz-40 cosmic ship joins the orbital Saliut 6 - Soiuz T-4. The moment of coupling was immortalized on the film inside the orbital station. The first to pass through the opening of the open traps of the two cosmic objects was Prunariu.

They spent seven days on the orbital station Saliut 6 . There, the two cosmonauts met with the Soviet cosmonauts Vladimir Kovalionok and Victor Savinich, who were already in the circumferential orbit on March $21,1981$.

For a week they worked together, carrying out 22 scientific experiments, including Capilar, Biodoza, Astro and Nanobalance. Biodose, for example, was related to the study of the Earth's magnetic field and its influence on living organisms. The vast majority of the experiments performed were of Romanian conception and the equipment made in Romania for this purpose was marked by a high degree of miniaturization, reliability and low energy consumption, functioning irreproachably. They aimed at gaining valuable information for expanding knowledge in the fields of astrophysics, nuclear physics and cosmic technology and biomedical experiments contribute to completing existing knowledge of human body behavior under the conditions specific to space flight as well as the advancement of fundamental research in the field aeronautical medicine and biology. The results obtained were used to prepare the flights that followed.

The crew complex with the crews on board went from night to day and inversely 16 times in $24 \mathrm{~h}$. As many times outside the cosmic devices, temperature variations of about 300 degrees Celsius $(+150$ degrees in the areas radiated by the Sun and -150 degrees during the shadow of the Earth) occurred. Prunariu had come to the performance of clinging to the cosmic diver costume that had 13 pounds during the record $7 \mathrm{~min}$. It has surrounded the Earth 125 times, crossing 5,260,000 km, at $28,500 \mathrm{~km} / \mathrm{h}$ in 7 days, $20 \mathrm{~h}, 42 \mathrm{~min}$ and $52 \mathrm{sec}$.

At about 19.30 - 20.00 I was passing over Romania every day. From there, from above, Romania saw the size of a home-made bread.

Like other cosmonauts, due to the changes occurring in the human body in imponderability, Dumitru Prunariu had, among other things, column pain in the lumbar region almost during the whole of the cosmic flight. "I almost woke up at 5 to 5:30 morning of pain and I felt the immediate need to move. In my spare time, for about an hour and a half, I watched through the cosmic 
station's mushrooms, admiring the beauties of the Earth. We said we went "to the beach" because the Sun "tan" (see burn) fast and powerful. The Romanian television also prepared us an artistic program on some primitive video tapes, but we did not manage to see too much of it. Sometimes we do green onions, "planted" in wet cloths.

The research program being concluded, the return from outer space took place on Friday, May 22, 1981, at 16.58, Romania time. The Soiuz 40 spacecraft's landing pad ( $2 / 3$ of the ship does not recover) landed near normal on land, according to the program, in the area established in the territory of the Soviet Union, 225 kilometers southeast of the city of Djezkazgan, from the Kazakh steppe. The landing was somewhat clever, with the parachute opening $4 \mathrm{sec}$ later, at less than $9,600 \mathrm{~km}$ as expected, which gave rise to all the great emotions. Describing the moments immediately after landing, Prunariu reports: "The shift to normal weight was terrible. I wake up picked up by four members of the search team and I'm sitting next to Popov lying on a lounger. I had the impression that I was lead and that the earth was shaking under me. Five minutes after the cosmos, as a comfort, I heard Romanian speaking, "confessed the cosmonaut, referring to Alexandru Stark, the reporter accredited to report the event. As dizzy as it was, helped by the other officials, Prunariu headed for the capsule to sign it, as usual.

The mission lasted 7 days, $20 \mathrm{~h}, 42 \mathrm{~min}$ and $52 \mathrm{sec}$, after a circumnavigation of 5,260,000 km.

At the time of the flight, Dumitru Prunariu was the 103rd cosmonaut of the world; since then, the number of cosmonauts has grown to over 450 and is steadily increasing. This flight of epicenter importance placed Romania in the select club of the participating countries directly to the exploration of the Universe and at the same time attests the tradition of the contributions of the great Romanian foremen to the flight of the man among the stars.

For the successful accomplishment of the cosmic flight, both Prunariu and Popov were decorated with the highest orders of Romania and the USSR. From a material point of view, for his historical achievement, Dumitru Prunariu received as a reward the equivalent of three salaries in the form of a premium granted by the Minister of Defense and was submitted one year before the term to captain. The authorities then were afraid of being denied by Ceausescu if he would make other rewarding proposals. Under these circumstances, having to move with his family in Bucharest where he received a post in the Military Aviation Command, Prunariu was forced to live half a year at a military home to get a home, then making numerous loans to arrange the apartment for the final settlement with the family in the capital of the country.

From 1981 until 1998, Prunariu was, with a break of almost two years, the chief inspector for aerospace activities at the Military Aviation Command and then the Aviation and Defense Staff Chief of Staff.
"This was a special function for me, which also had a strong side of representation. Of course, we have benefited from the support of military aviation, mainly to participate in cosmic activities both in the country and abroad. I have been asked many times to make my cosmic experience public."

In 1990 he was promoted to Colonel and was seconded to the Ministry of Transport for one and a half years to serve as Deputy Secretary of State and Head of the Civil Aviation Department (1990-1991).

In 1991 she graduated from the International Institute for Training and Aviation Management (IAMTI-IIFGA) in Montreal (Canada) for senior cadres. Since 1985 he has been a $\mathrm{PhD}$ student at the Aviation Institute in Bucharest. In 1999 he obtained the scientific title of Doctor of Engineer in the specialty "Aerospace Systems Dynamics".

In 1990 he presented the proposal for the establishment of the Romanian Space Agency, but its putting into practice was postponed. The agency was established by governmental decree in 1992 and in three years it was reorganized as an extra-budgetary public institution, working through a contract with the Ministry of Research and other institutions, including private ones. By government decision, the Romanian Space Agency represents Romania as a cosmic activity at the $\mathrm{UN}$, in relations with international or national agencies, such as the European Space Agency, NASA, CNES, etc.

\section{Results}

\section{George (Gogu) Constantinescu (4.Oct.1881 -} December 11, 1965)

Romanian scientist and engineer, often considered to be one of the most important Romanian engineers.

$\mathrm{He}$ was responsible for creating a new field of mechanics, called "sonicity," which describes the transmission of energy through vibrations in fluid or solid bodies. He applied the new theory to numerous inventions: sonic, sonic, sonic and others. Among other achievements, there is also a pulling device among the propeller blades regardless of its speed and the first automatic gearshift. He has actively participated in the construction of English aircraft, the Bristol type, while he lived in England.

Henri Marie Coanda (June 7, 1886 - November 25, 1972).

Academician and Romanian engineer, aviation pioneer, physicist, inventor, inventor of the reaction engine and discoverer of the effect that bears his name.

Henri Coanda was born in Bucharest on June 7, 1886, being the second child of a large family (Henri had four brothers and two sisters, a total of seven children). His father was General Constantine Coanda, a former mathematics professor at the National School of Bridges and Highways in Bucharest and former Prime Minister 
of Romania for a short period of time in 1918. His mother, Aida Danet, was the daughter of French doctor Gustave Danet.

Even from childhood, the future engineer and physicist was fascinated by the miracle of the wind, as he will later recall.

Henri Coanda was first a pupil of the Petrache Poenaru School in Bucharest, then of St. Sava High School in 1896 where he attended the first three classes, after which, at 13, he was sent by his father who wanted to guide him towards his career Military High School in Iasi, 1899. He graduated high school in 1903, receiving the rank of major sergeant and continuing his studies at the School of Artillery, Genius and Marine Officers in Bucharest.

In 1908 he returned to the country and was an active officer in the 2nd Artillery Regiment. Due to his nature and inventive spirit, who did not agree with military discipline, he sought and obtained approval to leave the army, after which, taking advantage of the reclaimed freedom, took a long journey by car on the IsfahanTehran-Tibet route.

On his way back to France, he enrolled in the Upper Aeronautics and Construction School, newly established in Paris, 1909, whose graduate becomes the next year in 1910 as the head of the first aeronautical engineer's promotion.

After completing his studies he worked at the Nice sites, led by the famous engineer Gustav Eiffel.

The PhD in Engineering has been very successful in Charlottenburg.

With the support of engineer Gustave Eiffel and scientist Paul Painlevé, who helped him get the necessary approvals, Henri Coanda performed the aerodynamic experiments and built the first reactive propulsion aircraft in Joachim Caproni's bodywork, a reaction plane, without a propeller, conventionally called Coanda-1910, which he presented at the second International Air Salon in Paris 1910.

Between 1911 and 1914 Henri Coanda worked as technical director at the Aviation Factories in Bristol, England and built high-performance propellers of his own design. In 1912, one of them (a bimonthly aircraft project - until then the planes had a single engine) won the first prize at the International Aviation Contest in England.

By manufacturing the apparatus called BristolCoanda, the plant has become one of the world's largest airplane manufacturing plants, selling its appliances in Germany, Italy, Spain and even Romania.

In the following years, he returns to France. In the years 1914-1918, Henri Coanda worked at SaintChamond and SIA-Delaunay-Belleville in Saint-Denis. During this period he designs three types of aircraft, the most famous of which is the Coanda-1916 reconnaissance plane, with two propellers close to the tail of the aircraft.
In 1934, he obtained a French patent for process and device for deviating a stream of fluid flowing into another fluid, which refers to the phenomenon called today the "Coanda Effect", consisting in the deviation of a stream of fluid flowing through along a convex wall, a phenomenon first observed by him in 1910, on the occasion of the test of the engine with which his reaction plane was equipped.

This effect has and still has precious applications in flight technology today.

Thus, the most modern flight machines use the Coanda effect for improved flight sustainability at low speeds and for increased comfort and safety.

And the Hercules C4 models use the Coanda effect today.

McDonnell Douglas YC-15 also uses the Coanda effect to make a comfortable journey at low speeds.

NOTAR helicopters have replaced the classic tail along with the classic rotor with a tail designed according to the Coanda effect.

Several aircraft, especially the Boeing YC-14 (the first modern type to exploit the effect), were built to take advantage of this effect by turbofan mounted on the top of the wing to provide a rapid flow of fluids besides fuselage, balance stability and better ship dynamics even at low speeds.

This discovery led Coanda to major applicative research on aerodynamic hypersurance, sound attenuators and more.

Coanda has been directly and indirectly involved in the development of various secret projects in the USA, Canada and the United Kingdom since the Second World War (the funds received for the completion of these strictly secret projects have even increased over the period cold war).

Canada "Avro VZ-9 Avrocar" was a VTOL aircraft developed by Avro Aircraft Ltd. (Canada) as part of a secret US military project in the early years of the Cold War.



Fig. 3: The aircraft became the "System 606A" weapon 
Two prototypes were built as "proof-of-concept" testing vehicles for a more advanced USAF fighter and also for the US Army (tactical combat aircraft).

The USAF agreed to take over Frost's Special Projects Group and immediately signed a US \$750,000 contract valid until 1955. By 1956, Avro's management received another $\$ 2.5$ million to build a prototype "private venture". In March 1957, Air Force added additional funding and the aircraft became the "System 606A" weapon, now manufactured in series (Fig. 3).

\section{Discussion}

Presented study proposes a commemoration of the main artisans of the Romanian and world aviation, from its beginnings to the day. Very briefly are brought to the forefront, the main inventors of flying machines and equipment that have lived here in the Romanian territory and have contributed substantially to the development of any type of flight. We will talk about Traian Vuia, Aurel Vlaicu, Alexandru N. Ciurcu, Hermann Julius Oberth, Elie Carafoli, Anastase Dragomir, Radu Manicatide, Iosif Silimon, Elena Caragiani-Stoenescu, Petre Constantinescu, Dumitru Dorin Prunariu, Henri Marie Coanda, George (Gogu) Constantinescu.

George (Gogu) Constantinescu (4.Oct.1881 December 11, 1965) was a Romanian scientist and engineer, often considered to be one of the most important Romanian engineers. He was responsible for creating a new field of mechanics, called "sonicity," which describes the transmission of energy through vibrations in fluid or solid bodies. He applied the new theory to numerous inventions: Sonic and others. Among other achievements, there is also a pulling device among the propeller blades regardless of its speed and the first automatic gearshift. He has actively participated in the construction of English aircraft, the Bristol type, while he lived in England.

Henri Marie Coanda (June 7, 1886 - November 25, 1972) was an Academician and Romanian engineer, aviation pioneer, physicist, inventor, inventor of the reaction engine and discoverer of the effect that bears his name. Henri Coanda was born in Bucharest on June 7, 1886 , being the second child of a large family (Henri had four brothers and two sisters, a total of seven children). His father was General Constantine Coanda, a former mathematics professor at the National School of Bridges and Highways in Bucharest and former Prime Minister of Romania for a short period of time in 1918. His mother, Aida Danet, was the daughter of French doctor Gustave Danet. Traian Vuia (August 17, 1872September 3, 1950) was a Romanian inventor and an aviation pioneer who designed, built and tested his own planes, which at the time were among the first heavier aircraft than the air.
On March 18, 1906, he made his first self-propelled flight (without catapults or other exterior means) with a heavier device than the air. In his first flight he managed to float about $12 \mathrm{~m}$ (40 feet) at Montesson in France on March 18, 1906 (see Fig. 1). This was the first "certified" flight with the take-off and landing of the aircraft (unassisted from the outside), made with a monoplane aircraft powered by a wheelchair. Performing a mechanical flight with a heavier machine than the air was a fascination at the end of the past and the beginning of our age. Thousands of fools tried to accomplish it, while the "balloons," who at the end of the eighteenth century had managed to rise in the balloons of the balloons, were smiling with superiority, convinced that the future is theirs, those with more aerial vehicles light than air.

\section{Conclusion}

Presented study proposes a commemoration of the main artisans of the Romanian and world aviation, from its beginnings to the day. Very briefly are brought to the forefront, the main inventors of flying machines and equipment that have lived here in the Romanian territory and have contributed substantially to the development of any type of flight. We will talk about Traian Vuia, Aurel Vlaicu, Alexandru N. Ciurcu, Hermann Julius Oberth, Elie Carafoli, Anastase Dragomir, Radu Manicatide, Iosif Silimon, Elena Caragiani-Stoenescu, Petre Constantinescu, Dumitru Dorin Prunariu, Henri Marie Coanda, George (Gogu) Constantinescu.

\section{Acknowledgement}

We acknowledge and thank Mr Taher M. AbuLebdeh, Associate Prof at North Carolina A and T State Univesity, United States and Mr Muftah H. El-Naas PhD MCIC FICCE QAFCO Chair Professor in Chemical Process Engineering Gas Processing Center College of Engineering Qatar University and Ms Shweta Agarwala, Senior Research Scientist at Singapore Center for 3D Printing Nanyang Technological University Singapore for their suggestions and comments.

\section{Funding Information}

Research contract: Contract number 36-5-4D/1986 from 24IV1985, beneficiary CNST RO (Romanian National Center for Science and Technology) Improving dynamic mechanisms internal combustion engines. All these matters are copyrighted. Copyrights: 548cgiywDssin, from: 22-04-2010, 08:48:48.

\section{Author's Contributions}

All the authors contributed equally to prepare, develop and carry out this manuscript. 


\section{Ethics}

This article is original and contains unpublished material. The corresponding author confirms that all of the other authors have read and approved the manuscript and no ethical issues involved.

\section{References}

Aversa, R., F.I.T. Petrescu, R.V. Petrescu and A. Apicella, 2016a. Biomimetic FEA bone modeling for customized hybrid biological prostheses development. Am. J. Applied Sci., 13: 1060-1067. DOI: 10.3844/ajassp.2016.1060.1067

Aversa, R., D. Parcesepe, R.V. Petrescu, G. Chen and F.I.T. Petrescu et al., 2016b. Glassy amorphous metal injection molded induced morphological defects. Am. J. Applied Sci., 13: 1476-1482. DOI: 10.3844/ajassp.2016.1476.1482

Aversa, R., R.V. Petrescu, F.I.T. Petrescu and A. Apicella, 2016c. Smart-factory: Optimization and process control of composite centrifuged pipes. Am. J. Applied Sci., 13: 1330-1341. DOI: 10.3844/ajassp.2016.1330.1341

Aversa, R., F. Tamburrino, R.V. Petrescu, F.I.T. Petrescu and M. Artur et al., 2016d. Biomechanically inspired shape memory effect machines driven by muscle like acting NiTi alloys. Am. J. Applied Sci., 13: 1264-1271. DOI: 10.3844/ajassp.2016.1264.1271

Aversa, R., E.M. Buzea, R.V. Petrescu, A. Apicella and M. Neacsa et al., 2016e. Present a mechatronic system having able to determine the concentration of carotenoids. Am. J. Eng. Applied Sci., 9: 1106-1111. DOI: 10.3844/ajeassp.2016.1106.1111

Aversa, R., R.V. Petrescu, R. Sorrentino, F.I.T. Petrescu and A. Apicella, 2016f. Hybrid ceramo-polymeric nanocomposite for biomimetic scaffolds design and preparation. Am. J. Eng. Applied Sci., 9: 1096-1105. DOI: 10.3844/ajeassp.2016.1096.1105

Aversa, R., V. Perrotta, R.V. Petrescu, C. Misiano and F.I.T. Petrescu et al., 2016g. From structural colors to super-hydrophobicity and achromatic transparent protective coatings: Ion plating plasma assisted $\mathrm{TiO} 2$ and $\mathrm{SiO} 2$ Nano-film deposition. Am. J. Eng. Applied Sci., 9: 1037-1045. DOI: 10.3844/ajeassp.2016.1037.1045

Aversa, R., R.V. Petrescu, F.I.T. Petrescu and A. Apicella, 2016h. Biomimetic and evolutionary design driven innovation in sustainable products development. Am. J. Eng. Applied Sci., 9: 1027-1036. DOI: 10.3844/ajeassp.2016.1027.1036

Aversa, R., R.V. Petrescu, A. Apicella and F.I.T. Petrescu, 2016i. Mitochondria are naturally micro robots-a review. Am. J. Eng. Applied Sci., 9: 991-1002.

DOI: 10.3844/ajeassp.2016.991.1002
Aversa, R., R.V. Petrescu, A. Apicella and F.I.T. Petrescu, 2016j. We are addicted to vitamins $\mathrm{C}$ and $\mathrm{E}-\mathrm{A}$ review. Am. J. Eng. Applied Sci., 9: 1003-1018. DOI: 10.3844 /ajeassp.2016.1003.1018

Aversa, R., R.V. Petrescu, A. Apicella and F.I.T. Petrescu, 2016k. Physiologic human fluids and swelling behavior of hydrophilic biocompatible hybrid ceramo-polymeric materials. Am. J. Eng. Applied Sci., 9: 962-972.

DOI: 10.3844/ajeassp.2016.962.972

Aversa, R., R.V. Petrescu, A. Apicella and F.I.T. Petrescu, 20161. One can slow down the aging through antioxidants. Am. J. Eng. Applied Sci., 9: 1112-1126. DOI: 10.3844/ajeassp.2016.1112.1126

Aversa, R., R.V. Petrescu, A. Apicella and F.I.T. Petrescu, $2016 \mathrm{~m}$. About homeopathy or «Similia similibus curentur 》. Am. J. Eng. Applied Sci., 9: 1164-1172. DOI: 10.3844/ajeassp.2016.1164.1172

Aversa, R., R.V. Petrescu, A. Apicella and F.I.T. Petrescu, 2016n. The basic elements of life's. Am. J. Eng. Applied Sci., 9: 1189-1197. DOI: 10.3844/ajeassp.2016.1189.1197

Aversa, R., F.I.T. Petrescu, R.V. Petrescu and A. Apicella, 2016o. Flexible stem trabecular prostheses. Am. J. Eng. Applied Sci., 9: 1213-1221. DOI: 10.3844/ajeassp.2016.1213.1221

Aversa, R., R.V.V. Petrescu, A. Apicella and F.I.T. Petrescu, 2017a. Nano-diamond hybrid materials for structural biomedical application. Am. J. Biochem. Biotechnol., 13: 34-41. DOI: 10.3844/ajbbsp.2017.34.41

Aversa, R., R.V. Petrescu, B. Akash, R.B. Bucinell and J.M. Corchado et al., 2017b. Kinematics and forces to a new model forging manipulator. Am. J. Applied Sci., 14: 60-80. DOI: 10.3844/ajassp.2017.60.80

Aversa, R., R.V. Petrescu, A. Apicella, I.T.F. Petrescu and J.K. Calautit et al., 2017c. Something about the $\mathrm{V}$ engines design. Am. J. Applied Sci., 14: 34-52. DOI: 10.3844/ajassp.2017.34.52

Aversa, R., D. Parcesepe, R.V.V. Petrescu, F. Berto and G. Chen et al., 2017d. Process ability of bulk metallic glasses. Am. J. Applied Sci., 14: 294-301. DOI: 10.3844/ajassp.2017.294.301

Aversa, R., R.V.V. Petrescu, B. Akash, R.B. Bucinell and J.M. Corchado et al., 2017e. Something about the balancing of thermal motors. Am. J. Eng. Applied Sci., 10: 200.217. DOI: 10.3844/ajeassp.2017.200.217

Berto, F., R.V.V. Petrescu and F.I.T. Petrescu, 2016a. A review of recent results on $3 \mathrm{D}$ effects. Am. J. Eng. Applied Sci., 9:1247-1260.

Berto, F., R.V.V. Petrescu and F.I.T. Petrescu, 2016 b. Three-dimensional in bonded joints: A short review. Am. J. Eng. Applied Sci., 9:1261-1268.

Berto, F., A. Gagani, R.V.V. Petrescu and F.I.T. Petrescu, 2016c. Key-hole notches in isostatic graphite: A review of some recent data. Am. J. Eng. Applied Sci., 9: 1292-1300. 
Berto, F., A. Gagani, R. Aversa, R.V.V. Petrescu and A. Apicella et al., 2016d. Multiaxial fatigue strength to notched specimens made of 40CrMoV13.9. Am. J. Eng. Applied Sci., 9: 1269-1291.

Mirsayar, M.M., V.A. Joneidi, R.V.V. Petrescu, F.I.T. Petrescu and F. Berto, 2017. Extended MTSN criterion for fracture analysis of soda lime glass. Eng. Fracture Mechan., 178: 50-59.

DOI: $10.1016 /$ j.engfracmech.2017.04.018

Petrescu, F.I.T. and J.K. Calautit, 2016a. About nano fusion and dynamic fusion. Am. J. Applied Sci., 13: 261-266.

Petrescu, F.I. and J.K. Calautit, 2016b. About the light dimensions. Am. J. Applied Sci., 13:321-325. DOI: 10.3844/ajassp.2016.321.325

Petrescu, F.I. and R.V. Petrescu, $2011 \mathrm{a}$. Memories about Flight. 1st Edn., CreateSpace, pp: 652.

Petrescu, F.I. and R.V. Petrescu, 2011b. Mechanical Systems, Serial and Parallel.1st Edn., lulu.com Publisher, London, UK. ISBN-10: 1446600394, pp: 124.

Petrescu, R.V. and F.I.T. Petrescu, 2012a. Northrop. 1st Edn., Books on Demand, ISBN-10: 3848209322 , pp: 142 .

Petrescu, F.I. and R.V. Petrescu, 2012b. New Aircraft II. 1st Edn., Books on Demand, pp: 138.

Petrescu, F.I. and R.V. Petrescu, 2012c. MecatronicaSisteme Seriale Si Paralele. 1st Edn., Create Space Publisher, USA, ISBN-13: 978-1-4750-6613-5, pp: 128.

Petrescu, F.I. and R.V. Petrescu, 2012d. Kinematics of the planar quadrilateral mechanism. Engevista, 14: 345-348.

Petrescu, F.I. and R.V. Petrescu, 2016a. Parallel moving mechanical systems kinematics. ENGE-VISTA, 18:455-491.

Petrescu, F.I. and R.V. Petrescu, 2016b. Direct and inverse kinematics to the anthropomorphic robots. ENGEVISTA, 18: 109-124.

Petrescu, F.I. and R.V. Petrescu, 2016c. Dynamic cinematic to a structure $2 \mathrm{R}$. Revista Geintec-Gestao Inovacao E Tecnol., 6: 3143-3154.

Petrescu, F.I.T., 2009. New aircraft. Proceedings of the 3rd International Conference on Computational Mechanics, Oct. 29-30, Brasov, Romania.

Petrescu, F.I.T., 2012a. Cold Nuclear Fusion. 1st Edn., Create Space, USA, ISBN-10: 1478234261, pp: 80.

Petrescu, F.I.T., 2012b. Particle Annihilation - a Source of Renewable Energy? Infinite Energy Magazine, LuLu Publishers, USA. http://blog.hasslberger.com/2012/02/particle_annihil ation_-_a sour.html

Petrescu, F.I.T. 2016 Valorificarea Traditiei Ingineresti Romanesti-I: Create Space Publisher, USA. 1st Edn., CreateSpace Independent Publishing Platform, ISBN-10: 1536889946, pp: 152.
Petrescu, R.V.V., R. Aversa, A. Apicella, F. Berto and S. $\mathrm{Li}$ et al., 2016a. Ecosphere protection through green energy. Am. J. Applied Sci., 13: 1027-1032.

Petrescu, F.I.T., A. Apicella, R.V.V. Petrescu, S.P. Kozaitis and R.B. Bucinell et al., 2016b. Environmental protection through nuclear energy. Am. J. Applied Sci., 13:941-946.

Petrescu, R.V., R. Aversa, A. Apicella and F.I. Petrescu, 2016c. Future medicine services robotics. Am. J. Eng. Applied Sci., 9: 1062-1087.

Petrescu, R.V. and F.I. Petrescu, 2013a. Lockheed Martin. 1st Edn., CreateSpace, pp: 114.

Petrescu, R.V. and F.I. Petrescu, 2013b. Northrop. 1st Edn., CreateSpace, pp: 96.

Petrescu, R.V. and F.I. Petrescu, 2013c. The Aviation History or New Aircraft I Color. 1st Edn., CreateSpace, pp: 292.

Petrescu, F.I. and R.V. Petrescu, 2013d. Cinematics of the 3R Dyad. Engevista, 15: 118-124.

Petrescu, R.V., R. Aversa, B. Akash, F. Berto and A. Apicella et al., 2017a. Forces of a 3R robot. J. Mechatron. Robotics, 1: 1-14.

Petrescu, R.V., R. Aversa, B. Akash, F. Berto and A. Apicella et al., 2017b. Direct geometry and cinematic to the MP-3R systems. J. Mechatron. Robotics, 1: 15-23.

Petrescu, R.V., R. Aversa, B. Akash, F. Berto and A. Apicella et al., 2017c. Dynamic elements at MP3R. J. Mechatron. Robotics, 1: 24-37.

Petrescu, R.V., R. Aversa, B. Akash, F. Berto and A. Apicella et al., 2017d. Geometry and direct kinematics to MP3R with $4 \times 4$ operators. J. Mechatron. Robotics, 1: 38-46.

Petrescu, R.V., R. Aversa, A. Apicella, M.M. Mirsayar and S. Kozaitis et al., 2017e. Current stage in the field of mechanisms with gears and rods. J. Mechatron. Robotics, 1: 47-57.

Petrescu, R.V., R. Aversa, A. Apicella, M.M. Mirsayar and S. Kozaitis et al., 2017f. Geometry and inverse kinematic at the MP3R mobile systems. J. Mechatron. Robotics, 1: 58-65.

Petrescu, R.V., R. Aversa, A. Apicella, M.M. Mirsayar, S. Kozaitis and T. Abu-Lebdeh et al., $2017 \mathrm{~g}$. Synthesis of optimal trajectories with functions control at the level of the kinematic drive couplings. J. Mechatron. Robotics, 1: 66-74.

Petrescu, R.V., R. Aversa, A. Apicella, M.M. Mirsayar and S. Kozaitis et al., 2017h. The inverse kinematics of the plane system 2-3 in a mechatronic MP2R system by a trigonometric method. J. Mechatron. Robotics, 1: 75-87.

Petrescu, R.V., R. Aversa, A. Apicella, M.M. Mirsayar and S. Kozaitis et al., 2017i. Serial, anthropomorphic, spatial, mechatronic systems can be studied more simply in a plan. J. Mechatron. Robotics, 1: 88-97. 
Petrescu, R.V., R. Aversa, A. Apicella, M.M. Mirsayar and S. Kozaitis et al., 2017j. Analysis and synthesis of mechanisms with bars and gears used in robots and manipulators. J. Mechatron. Robotics, 1: 98-108.

Petrescu, RV., R. Aversa, A. Apicella, M.M. Mirsayar and S. Kozaitis et al., 2017k. Speeds and accelerations in direct kinematics to the MP3R systems. J. Mechatron. Robotics, 1: 109-117.
Petrescu, R.V., R. Aversa, A. Apicella, M.M. Mirsayar and S. Kozaitis et al., 20171. Geometry and determining the positions of a plan transporter manipulator. J. Mechatron. Robotics, 1: 118-126.

\section{Source of Figures}

(Petrescu, 2016) 